\title{
HUBUNGAN ANTARA KADAR SERUM INTERFERON GAMMA DENGAN DERAJAT KEPARAHAN PSORIASIS VULGARIS
}

\author{
Wardhana M, Suryawati N, Praharsini IGAA, Indira E IGAA \\ Bagian/SMF Ilmu Kesehatan Kulit dan Kelamin \\ FK Universitas Udayana/RSUP Sanglah Denpasar
}

\begin{abstract}
ABSTRAK
Interferon gamma (IFN- $\gamma)$ merupakan mediator inflamasi yang penting pada penyakit psoriasis vulgaris. Berdasarkan penelitian sebelumnya didapatkan hubungan antara peningkatan kadar IFN- $\gamma$ dengan derajat keparahan psoriasis vulgaris. Penelitian ini bertujuan untuk mengetahui hubungan antara kadar serum IFN- $\gamma$ dengan derajat keparahan psoriasis vulgaris. Metode penelitian adalah cross-sectional dengan sampel pasien psoriasis vulgaris dan bukan psoriasis vulgaris, berumur 16-65 tahun, yang berkunjung ke Poliklinik Kulit dan Kelamin RSUP Sanglah pada periode Oktober sampai Desember 2017, berdasarkan kriteria inklusi dan eksklusi. Penelitian ini melibatkan 70 orang sampel yang terdiri atas 42 orang pasien psoriasis dan 28 orang bukan psoriasis sebagai pembanding. Hasil penelitian didapatkan pasien psoriasis terbanyak berjenis kelamin

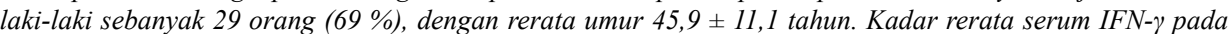
pasien psoriasis didapatkan 2,95 $\pm 2,29 \mathrm{ng} / \mathrm{mL}$ (IK 95\%: 2,29-3,80 $\mathrm{ng} / \mathrm{mL}$ ) lebih tinggi dibandingkan dengan bukan psoriasis 2,14 $\pm 1,78 \mathrm{ng} / \mathrm{mL}$ (IK 95\%:1,74-2,63ng/mL) dengan perbedaan rerata kadar serum IFN- $\gamma$ pada kedua kelompok adalah $0,81 \mathrm{ng} / \mathrm{mL}$ dan bermakna secara statistik $(p<0,001)$. Pada studi ini berdasarkan grafik scattered plot ditemukan bahwa peningkatan kadar serum IFN- $\gamma$ berkorelasi positif $(r=0,603)$ dengan derajat keparahan psoriasis vulgaris dan nilai skor PASI dipengaruhi oleh peningkatan kadar serum IFN- $\gamma$ sebesar $28,7 \%(R 2=0,287)$.
\end{abstract}

Kata Kunci: Interferon gamma, skor PASI, psoriasis vulgaris

\section{THE CORRELATION BETWEEN INTERFERON GAMMA SERUM LEVEL AND SEVERITY OF PSORIASIS VULGARIS}

\begin{abstract}
Interferon gamma $(I F N-\gamma)$ is an inflammatory mediator which plays an important role in psoriasis vulgar-

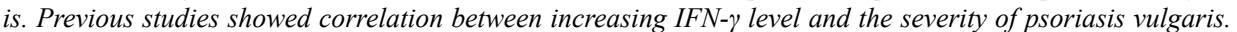
The aim of this study is to find out about the correlation of IFN- $\gamma$ serum level and the severity of psoriasis vulgaris. Methode of the study was cross-sectional with the subjects were patients with psoriasis vulgaris and patients without psoriasis vulgaris aged 16-65 years old who came to Dermatology and Venereology Outpatient Center at Sanglah General Hospital during the period October-December 2017 and fulfilled the inclusion and exclusion criteria. The study involved 70 subjects, consisted of 42 psoriasis patients and 28 non-psoriasis patients as the control group. The result of this study showed majority of psoriasis patient were male (29 people; $69 \%$ aged 45,9 11,1 years old on average. Mean level of IFN- $\gamma$ serum was higher in psoriasis group are 2,95 $\pm 2,29 \mathrm{ng} / \mathrm{mL}$ (CI 95\%: 2,29-3,80) compared to non-psoriasis group 2,14 $\pm 1,78 \mathrm{ng} / \mathrm{mL}(C I$ 95\%:1,74-2,63) and the mean deferences between both group are $0,81 \mathrm{ng} / \mathrm{mL}$ with statistically significant ( $p$-value $<0.001)$. This study revealed that the increasing of IFN- $\gamma$ has a positive correlation $(r=0.603)$ with the degree of severity in psoriasis vulgaris and the value of PASI score was influenced by the increase of serum IFN- $\gamma$ level of $28.7 \%$ $(R 2=0.287)$.
\end{abstract}

Keywords: Interferon gamma, PASI score, psoriasis vulgaris

Korespondensi:

J1. Diponegoro, Denpasar, Bali

Telp/ Fax : 0361-257517/0361-239993

Email: suryawati@unud.ac.id 


\section{PENDAHULUAN}

Psoriasis vulgaris merupakan penyakit kulit autoimun kronis yang ditandai dengan gambaran klinis berupa plak eritematosa berbatas tegas ditutupi skuama putih berlapis disertai dengan fenomena tetesan lilin, Auspitz, dan Koebner. Penyakit ini bersifat kronis dan rekuren, pasien dapat mengalami periode remisi dan eksaserbasi. Prevalensi psoriasis vulgaris dilaporkan bervariasi antara $0,1 \%$ hingga $3 \%$ dengan prevalensi tertinggi dilaporkan di Denmark (2,9\%), dan dilaporkan rendah di Asia $(0,4 \%){ }^{1}$

Patogenesis psoriasis vulgaris bersifat kompleks, meliputi faktor genetik, defek imunitas, hormon, dan faktor lingkungan. ${ }^{1-3}$ Ekspresi berlebihan sitokin proinflamasi, yaitu interleukin (IL)-1, IL-6, IL-10, interferon- $\gamma$ (IFN- $\gamma$ ), tumor necrosis factor- $\alpha$ (TNF- $\alpha$ ) berperan pada patogenesis psoriasis vulgaris. ${ }^{4}$ Sitokin IFN- $\gamma$ berperan dalam aktivasi regulasi respons imun, proliferasi dan diferensiasi sel T, sel B, makrofag, fibroblas, dan sel endothel. IFN- $\gamma$ menstimulasi produksi berbagai mediator pro-inflamasi, misalnya IL-1, IL-6, IL-8, IL-12, IL-15, TNF, protein 10 yang diinduksi IFN (IP-10), sintesis nitric oxid synthase (Inos), kaspase-1 dan gp91phox (NOX2). IFN- $\gamma$ juga menstimulasi sel dendritik (DC) untuk memproduksi IL-1 dan IL-23 yang merupakan sitokin promoting Th17 dan Th22. Studi terbaru menunjukkan sel Th17 dapat memproduksi IFN- $\gamma$. Produksi antibodi, ekspresi major histocompatibility complex (MHC) kelas I dan II pada antigen presenting cell (APC), ekspresi intercellular adhesion molecule (ICAM)-1 pada keratinosit ditingkatkan oleh IFN- $\gamma$ sebagai respons terhadap antigen. ${ }^{5}$

Kadar serum IFN- $\gamma$ didapatkan meningkat pada pasien psoriasis vulgaris. ${ }^{4,5}$ Uyemura dkk, mendapatkan ekspresi IFN- $\gamma$ ditemukan pada lesi psoriasis maupun pada kulit non lesi. ${ }^{5}$ Kadar serum IFN- $\gamma$ berhubungan dengan derajat keparahan dan dapat digunakan untuk memonitor respons terapi pada psoriasis vulgaris. ${ }^{4}$ Jadali dkk. (2007), mendapatkan korelasi antara kadar serum IFN $-\gamma$ dengan derajat keparahan psoriasis tipe plak sehingga mendukung peranan sel Th-1 pada patogenesis psoriasis vulgaris. ${ }^{6}$

Penelitian sebelumnya menyatakan bahwa serum IFN- $\gamma$ merupakan faktor risiko untuk terjadinya psoriasis. Interferon-gamma diduga berperan penting dalam patogenesis psoriasis vulgaris yaitu pada awal lesi psoriasis yang ditunjukkan dengan terjadinya titik-titik lesi psoriasis pada lokasi kulit yang sebelumnya diinjeksi dengan IFN- $\gamma$. ${ }^{7}$ IFN- $\gamma$ penting pada tahap awal psoriasis, berperan meningkatkan migrasi sel imun ke dalam kulit dan aktivasi monosit, makrofag, sel dendritik serta sel endotel. IFN- $\gamma$ juga menghambat apoptosis keratinosit, berperan pada terjadinya hiperproliferasi keratinosit dan merangsang proliferasi sel epidermis. ${ }^{8}$ Sitokin IFN- $\gamma$ ber- peran dalam aktivasi regulasi respons imun, proliferasi dan diferensiasi sel T, sel B, makrofag, fibroblast, dan sel endotel. IFN- $\gamma$ menstimulasi produksi berbagai mediator pro-inflamasi seperti IL-1, IL-6, IL-8, IL-12, IL-15, TNF, protein10 yang diinduksi IFN (IP-10), sintesis nitric oxid synthase (Inos), kaspase-1 dan gp91phox (NOX2). IFN- $\gamma$ juga menstimulasi sel dendritik (DC) untuk memproduksi IL-1 dan IL-23 yang merupakan sitokin promoting Th17 dan Th22. Studi terbaru menunjukkan sel Th17 dapat memproduksi IFN- $\gamma$. Produksi antibodi, ekspresi MHC kelas I dan II pada antigen presenting cell (APC), ekspresi ICAM-1 pada keratinosit ditingkatkan oleh IFN- $\gamma$ sebagai respons terhadap antigen. ${ }^{5}$ Ikatan dan sinyal IFN- $\gamma$ didapatkan lemah pada psoriasis vulgaris. Reseptor IFN- $\gamma$, signal transducer dan aktivator transkripsi STAT-1 dan interferon regulatory factor-1 didapatkan menurun pada psoriasis vulgaris. IFN- $\gamma$ menurunkan regulasi ekspresi enzim katalitik cathepsin-D dan glikoprotein zinc- $\alpha 2$ pada lesi psoriasis dan meningkatkan regulasi supresi apoptosis bcl-2. Hasil ini menunjukkan peran penting IFN- $\gamma$ pada patogenesis psoriasis vulgaris, yaitu gangguan pada apoptosis dan deskuamasi. ${ }^{7}$ Penelitian ini bertujuan mengetahui hubungan antara kadar serum IFN- $\gamma$ dengan derajat keparahan psoriasis vulgaris.

\section{METODE PENELITIAN}

Penelitian ini menggunakan rancangan penelitian coss-sectional dengan jumlah sampel 70 orang terdiri atas 42 orang pasien psoriasis dan 28 orang bukan psoriasis sebagai kelompok pembanding. Sampel merupakan pasien psoriasis maupun bukan psoriasis vulgaris berumur $\geq 15-65$ tahun, yang berkunjung ke poliklinik kulit dan kelamin RSUP Sanglah yang terpilih berdasarkan kriteria inklusi dan ekslusi, pada periode Oktober hingga Desember 2017. Diagnosis psoriasis vulgaris ditegakkan berdasarkan anamnesis dan pemeriksaan fisik. Pemeriksaan histopatologis dilakukan pada kasus yang meragukan.

Penilaian derajat keparahan psoriasis vulgaris dilakukan dengan menggunakan skor Psoriasis Area and Severity Index (PASI). Skor PASI adalah pengukuran secara klinis luas daerah yang terkena dan derajat keparahan dari eritema, ketebalan infiltrat dan skuama dengan menggunakan rumus: $\{0,1(\mathrm{Eh}+\mathrm{Ih}+\mathrm{Sh}) \mathrm{Ah}\}+\{0,2$ $(\mathrm{Eul}+\mathrm{Iul}+\mathrm{Sul}) \mathrm{Aul}\}+\{0,3(\mathrm{Et}+\mathrm{It}+\mathrm{St}) \quad \mathrm{At}\}+\{0,4$ $($ Ell+Ill+Sll $)$ All $\}$. Keterangan: A (area) $=$ luas permukaan tubuh dalam 4 bagian yang terkena yaitu: kepala dan leher $(\mathrm{h}=$ head $)$, badan $(\mathrm{t}=$ trunk $)$, ekstremitas atas $(\mathrm{ul}=$ upper $\lim b)$, ekstremitas bawah $(11=$ lower $\operatorname{limb})$ dengan skor 1-6. $\mathrm{E}=$ eritema; $\mathrm{I}=$ infiltrat; $\mathrm{S}=$ skuama dengan skor 0-4.7 Total skor PASI mulai dari 0 sampai 72. Skor PASI dinilai ringan (skor $<7$ ), sedang (skor 


\section{7-12), dan berat (skor $>12) .{ }^{9}$}

Kadar serum IFN- $\gamma$ diperiksa dengan mengambil darah vena sebanyak $3 \mathrm{cc}$ antara pukul 08.00 hingga 10.00 WITA. Penilaian kadar serum IFN- $\gamma$ dengan menggunakan metoda ELISA.

Data diolah menggunakan peranti lunak SPSS-20. Analisis deskriptif untuk menilai karakteristik subyek penelitian. Untuk menguji normalitas data menggunakan Kolmogorov-Smirnov. Perbedaan rerata kadar serum IFN- $\gamma$ kelompok psoriasis dan bukan psoriasis dilakukan dengan uji $\mathrm{T}$ tidak berpasangan. Korelasi antara kadar serum IFN- $\gamma$ dengan derajat keparahan psoriasis (skor PASI) menggunakan analisis korelasi (uji Spearman's $r h o)$. Analisis statistik dinyatakan bermakna bila nilai $\mathrm{p}<0,05$

\section{HASIL PENELITIAN}

Penelitian ini melibatkan 70 orang subyek terdiri atas 42 orang pasien psoriasis vulgaris dan 28 orang bukan psoriasis vulgaris sebagai kelompok pembanding. Pada kelompok psoriasis vulgaris didapatkan rerata umur adalah 45,9 $\pm 11,1$ tahun, terbanyak pada kelompok umur 46-55 tahun (38,2\%), berjenis kelamin laki-laki $(69,0 \%)$, suku Bali (83,3\%), tingkat pendidikan SMA $(47,6 \%)$ dengan bekerja di sektor swasta $(52,4 \%)$. Pada kelompok bukan psoriasis vulgaris didapatkan rerata umur adalah $33,8 \pm 8,3$ tahun, terbanyak pada kelompok umur 26-35 tahun $(57,1 \%)$, berjenis kelamin perempuan $(71,4 \%)$, suku Bali $(75,7 \%)$, tingkat pendidikan sarjana $(60,7 \%)$ dengan bekerja di sektor swasta $(65,7 \%)$. Pada penelitian ini terdapat perbedaan umur antara kelompok psoriasis dan bukan psoriasis $(\mathrm{p}<0,05)$. Hal ini kemungkinan disebabkan karena rentang umur sampel pada penelitian cukup besar yaitu pada umur $\geq 15-65$ tahun.

Berdasarkan riwayat lamanya menderita psoriasis vulgaris didapatkan terbanyak pada rentang 1-5 tahun $(47,6 \%)$ dengan rerata lama menderita psoriasis adalah $6,5 \pm 7,6$ tahun dengan nilai median skor PASI adalah $12,6 \pm 11,5$.

Rerata skor PASI pada penelitian ini didapatkan 12,6 $\pm 11,5$. Rerata kadar serum IFN- $\gamma$ pada kelompok psoriasis vulgaris didapatkan $2,95 \pm 2,29 \mathrm{ng} / \mathrm{mL}$ (IK 95\%: 2,29-3,80), sedangkan nilai rerata serum IFN- $\gamma$ pada kelompok bukan psoriasis adalah: $2,14 \pm 1,78 \mathrm{ng} / \mathrm{mL}$ (IK 95\%; 1,74-2,63). Perbedaan rerata antara kelompok psoriasis dan bukan psoriasis adalah $0,81 \mathrm{ng} / \mathrm{mL}$. Perbedaan nilai rerata pada kedua kelompok bermakna secara statistik (nilai $p=0,000$ ). Data rerata kadar serum IFN- $\gamma$ pada kelompok psoriasis dan bukan psoriasis dapat dilihat pada tabel 1.

Tabel 1. Perbedaan rerata kadar serum IFN- $\gamma$ pada kelompok psoriasis dan bukan psoriasis.

\begin{tabular}{lccc}
\hline \multicolumn{1}{c}{ Variabel } & $\begin{array}{c}\text { Kelompok psoriasis } \\
(\mathrm{n}=42)\end{array}$ & $\begin{array}{c}\text { Kelompok bukan } \\
\text { psoriasis }(\mathrm{n}=28)\end{array}$ & Nilai p \\
\hline Rerata kadar serum IFN- $\gamma$ & 2,95 & 2,14 & $\mathrm{p}<0,001$ \\
Simpang baku & 2,29 & 1,78 & \\
Nilai terendah & 2,29 & 1,74 & \\
Nilai tertinggi & 3,80 & 2,63 & \\
\hline
\end{tabular}

Pada penelitian ini didapatkan peningkatan kadar serum IFN- $\gamma$ berkorelasi positif dengan derajat keparahan psoriasis vulgaris $(r=0,603 ; p<0,05)$. Korelasi antara kadar serum IFN- $\gamma$ dengan derajat keparahan psoriasis (skor PASI) dapat dilihat pada gambar 1.

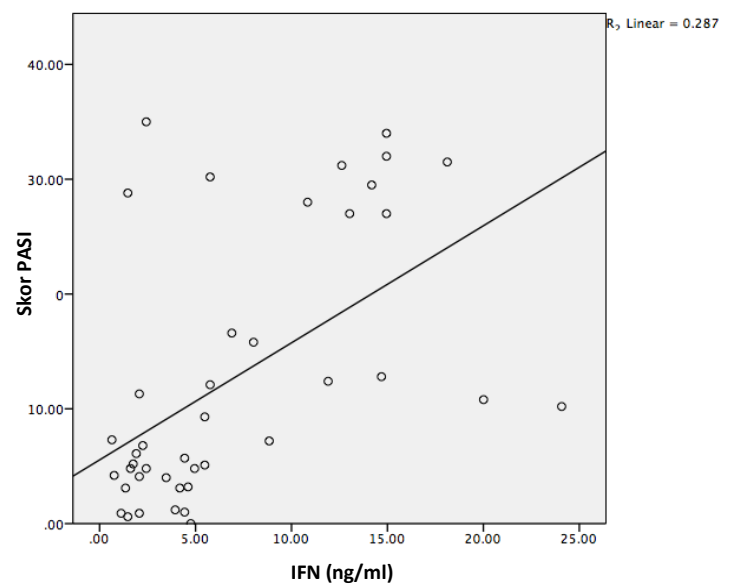

Gambar 1. Diagram scattered plot korelasi antara kadar serum IFN- $\gamma$ dengan skor PASI

\section{DISKUSI}

Pada penelitian ini, rerata umur pasien psoriasis adalah 45,93 $\pm 11,07$ tahun. Hasil ini sesuai dengan penelitian di India (2014) yang menyatakan rerata umur pasien psoriasis adalah 49,45 $\pm 14,8$ tahun, maupun studi di Kroasia (2013) dengan rerata umur 49,9 $\pm 14,8$ tahun. Psoriasis dapat terjadi pada semua umur, cenderung terjadi pada usia dewasa dibandingkan dengan usia anak. Studi di Norwegia, Skotlandia, Spanyol dan Taiwan menunjukkan usia puncak pertama psoriasis terjadi pada usia 20-29 tahun atau 30-39 tahun. Beberapa studi di Inggris, Jerman, dan Rusia menunjukkan peningkatan usia psoriasis sampai berkisar 60 tahun dan setelah usia 60 tahun terjadi penurunan prevalensi psoriasis. ${ }^{10}$

Rerata kadar serum IFN- $\gamma$ pada kelompok psoriasis adalah 2,95 $\pm 2,29 \mathrm{ng} / \mathrm{mL}$ (IK 95\%: 2,29-3,80), sedangkan pada kelompok bukan psoriasis didapatkan 2,14 \pm $1,78 \mathrm{ng} / \mathrm{mL}$ (IK 95\%: 1,74-2,63). Pada analisis statistik didapatkan bahwa rerata kadar serum IFN- $\gamma$ pada kelompok psoriasis secara bermakna lebih tinggi dibandingkan dengan kelompok bukan psoriasis dengan perbedaan re- 
rata pada kedua kelompok adalah $0,81 \mathrm{ng} / \mathrm{mL}(\mathrm{p}<0,001)$. Hasil ini sesuai dengan studi oleh Moustafa dkk. (2009) yang menyatakan terdapat perbedaan rerata kadar serum IFN- $\gamma$ antara kelompok pasien psoriasis vulgaris $(24,52 \pm$ $18,09 \mathrm{ng} / \mathrm{mL}$ ) dengan kelompok kontrol bukan psoriasis vulgaris $(8,33 \pm 2,27 \mathrm{ng} / \mathrm{mL})$ yang berbeda bermakna secara statistik. ${ }^{7}$ Perbedaan antara kadar rerata serum IFN- $\gamma$ penelitian ini kemungkinan disebabkan oleh pemilihan sampel pasien psoriasis dengan kondisi penyakit yang lebih ringan dibandingkan dengan studi oleh Moustafa dkk. Pada penelitian Moustafa dkk, didapatkan kadar rerata serum IFN- $\gamma$ pada kelompok psoriasis dengan skor PASI $<15$ adalah $16,39 \pm 13,9 \mathrm{ng} / \mathrm{mL}$, sedangkan pada kelompok psoriasis dengan skor $>15$ adalah $35,9 \pm 17,61$ $\mathrm{ng} / \mathrm{mL}^{7}$

Pada penelitian ini didapatkan korelasi positif antara peningkatan kadar serum IFN- $\gamma$ terhadap nilai skor PASI dengan nilai korelasi sedang $(\mathrm{r}=0,603)$ dan bermakna secara statistik $(\mathrm{p}<0,05)$. Nilai skor PASI dipengaruhi oleh peningkatan kadar serum IFN- $\gamma$ sebesar 28,7\% ( $\mathrm{R} 2=0,287)$. Hal ini menunjukkan bahwa masih terdapat faktor lain yang berpengaruh pada derajat keparahan psoriasis vulgaris.

Uyemura dkk. mendapatkan ekspresi IFN- $\gamma$ ditemukan pada lesi psoriasis maupun pada kulit non lesi. ${ }^{5}$ Kadar serum IFN- $\gamma$ berhubungan dengan derajat keparahan dan

\section{DAFTAR PUSTAKA}

1. Gudjonsson JE. Psoriasis. Dalam: Goldsmith LA, Katz SI, Gilchrest BA, Paller AS, Leffel DJ, dkk. Penyunting. Fitzspatrick's Dermatology in General Medicine. Edisi ke- 8 New York: McGraw-Hill; 2012. h. 197-231.

2. Griffiths CEM, Barker JNWN. Psoriasis. Dalam: Burn T, Breathnach S, Cox N, Graffiths C. Penyunting. Rook's Textbook of Dermatology. Edisi ke-8. Brithish: Wiley-Blackwell; 2010. h. 20.1-20.60.

3. Gerkowicz A, Pietrzak A, Szepietowski J, Radej S, Chodorowska G. Biochemical markers of psoriasis as a metabolic disease. Folia Histochem Cytobiol 2012. 50:155-70.

4. Jacob S, Nasiri M, Kerdel F, Vinchek V. Simultaneous measurement of multiple Th1 and Th2 serum cytokines in psoriasis and correlation with disease severity. Mediat Inflamm 2003. 12:309-13

5. Michalak A, Pietrzak A, Szepietowski J, Zalewska A, Paszkowski T, Chodorowska G. Cytokine network in psoriasis revisited. Eur Cytokine Netw 2011. 22:160-8. dapat digunakan untuk memonitor respons terapi pada psoriasis vulgaris. ${ }^{4}$ Jadali dkk. mendapatkan korelasi antara kadar serum IFN- $\gamma$ dengan derajat keparahan psoriasis tipe plak sehingga mendukung peranan sel Th-1 pada patogenesis psoriasis vulgaris. ${ }^{6}$ Kadar IFN- $\gamma$ meningkat pada psoriasis aktif dan berkorelasi dengan skor PASI. ${ }^{8}$ Korelasi kadar serum IFN- $\gamma$ dengan skor PASI juga didapatkan pada penelitian oleh Gomi dkk. dan Moustafa dkk. yang mendapatkan peningkatan kadar serum IFN- $\gamma$ berkorelasi positif dengan nilai skor PASI. ${ }^{7}$

\section{SIMPULAN}

Pada penelitian terdapat perbedaan rerata kadar serum IFN- $\gamma$ antara pasien psoriasis dan bukan psoriasis, sebesar $0,81 \mathrm{ng} / \mathrm{ml}$. Rerata kadar serum IFN- $\gamma$ pada kelompok psoriasis adalah 2,95 $\pm 2,29 \mathrm{ng} / \mathrm{mL}$ (IK 95\%; 2,29-3,80), sedangkan pada kelompok bukan psoriasis kadar serum IFN- $\gamma$ adalah 2,14 $\pm 1,78 \mathrm{ng} / \mathrm{mL}$ (IK $95 \% ; 1,74-2,63)$ yang terbukti bermakna secara statistik $(\mathrm{p}<0,05)$. Terdapat korelasi sedang $(\mathrm{r}=0,603)$ antara kadar serum IFN- $\gamma$ dengan skor PASI dan bermakna secara statistik $(p<0,05)$. Nilai skor PASI dipengaruhi oleh peningkatan kadar serum IFN- $\gamma$ sebesar 28,7\% $(\mathrm{R} 2=0,287)$ yang menunjukkan terdapat faktor lain yang berperan dalam derajat keparahan psoriasis vulgaris.

6. J Jadali Z, Izad M, Eslami M, Mansouri P, Safari R, Bayatian P, dkk. Th1/Th2 Cytokines in Psoriasis. Iran J Publ Health 2007. 36:87-91.

7. Moustafa YM, Aal IAA, Elarman M, Baky AA, Taher S. Assessment of Serum Interferon Gamma and Interleukin-4 in Psoriasis Vulgaris. Egypt J Med Microbiol. 2009;18:45-50.

8. Diluvio L, Vollmer S, Besgen P, Ellwart J, Chimenti S, Prinz J. Identical TCR $\beta$-Chain Rearrangements in Streptococcal Angina and Skin Lesions of Patients with Psoriasis Vulgaris. Yearb Dermatol Dermatol Surg. 2007;176:7104-11

9. Langley R, Ellis C. Evaluating psoriasis with Psoriasis Area and Severity Index, Psoriasis Global Assessment, and Lattice System Physician's Global Assessment. J Am Acad Dermatol 2004. 51:563-9.

10. Parisi R. Global epidemiology of psoriasis: A Systematic review of incidence and prevalence. J Invest Dermatol. 2013;133:377-85. 